DOI :https ://doi.org//10.33369/ijts. 13.1.41-47

\title{
FAKTOR FAKTOR YANG BERPENGARUH TERHADAP MODEL BANGKITAN PERJALANAN BEKERJA PADA KAWASAN PERUMAHAN DI KECAMATAN MUARA BANGKAHULU KOTA BENGKULU
}

\author{
Samsul Bahri ${ }^{1)}$, Bella Friska Nanda ${ }^{1)}$,Makmun Reza Razali ${ }^{1)}$ \\ ${ }^{1)}$ Fakultas Teknik Universitas Bengkulu \\ Jl. W.R. Supratman, Kandang Limun, Bengkulu, 38371 \\ Corresponding author : sbahri@unib.ac.id
}

\begin{abstract}
Abstrak
Meningkatnya aktivitas bangkitan pergerakan kendaraan di suatu ruas jalan mencerminkan perkembangan yang terjadi di wilayah tersebut. Aktivitas masyarakat dalam bentuk perjalanan untuk bekerja, dapat mempengaruhi besarnya bangkitan pergerakan. Penelitian ini bertujuan untuk mengetahui faktor-faktor yang berpengaruh terhadap model bangkitan perjalanan bekerja pada Kawasan Perumahan di Kecamatan Muara Bangkahulu. Metode penelitian dengan cara wawancara langsung dalam bentuk kuesioner. Analisis data penelitian menggunakan model regresi linier berganda. Hasil penelitian menunjukkan bahwa model bangkitan perjalanan pada Kawasan Perumahan di Kecamatan Muara Bangkahulu memiliki persamaan y $=-0,961+0,173$ $\mathrm{x}_{1}+0,193 \mathrm{x}_{4}+1,257 \mathrm{x}_{5}, \mathrm{r}^{2}=0,886$ dengan faktor yang mempengaruhi adalah jumlah anggota keluarga $\left(\mathrm{x}_{1}\right)$, jumlah penghasilan rata-rata keluarga perbulan $\left(\mathrm{x}_{4}\right)$ dan jumlah anggota keluarga bekerja $\left(\mathrm{x}_{5}\right)$.
\end{abstract}

Kata kunci:model bangkitan, perjalanan bekerja, kawasan perumahan

\begin{abstract}
The increased activity of trip generation vehicle on a road section reflects the redional. People's trip to work can affect the magnitude of the trip generation. This study aims to determine the factors that influence the work trip generation model in the residential area in Muara Bangkahulu District. The research method is by means of direct interviews in the form of a questionnaire. Data analysis used multiple linear regression models. The results showed that the trip generation model in the Residential Area in Muara Bangkahulu District has the equation $y=-0,961+0,173 x_{1}+0,193 x_{4}+1,257 x_{5} ; r 2=0,886$ with the influencing factor is the number of family members $\left(x_{1}\right)$, the amount of average income, family per month $\left(x_{4}\right)$ and the number of working family members $\left(x_{5}\right)$.
\end{abstract}

Keywords: trip generation, work trip, residential area 


\section{PENDAHULUAN}

Ciri umum berkembangnya suatu kota adalah meningkatnya kebutuhan terhadap tempat tinggal.Perumahan sebagai salah satu wujud dari penyediaan tempat tinggal bagi masyarakat,merupakan lahan bisnis yang menjanjikan bagi para pengusaha pengembang perumahan (developer).

Daerah pinggiran kota secara umum masih memiliki lahan kosong yang cukup luas. Kondisi ini memungkinkan kawasan pinggiran perkotaan untuk tumbuh dan berkembang. Berkembangnya kawasan pinggiran perkotaandapat dilihat dengan meningkatnya aktivitas bangkitan pergerakan perjalanan masyarakat di wilayah tersebut. Bangkitan pergerakan perjalanan masyarakat terjadi karena adanya aktivitas untuk memenuhi kebutuhan hidup.

\section{TINJAUAN PUSTAKA}

\section{Transportasi}

Transportasi berasal dari bahasa latin yaitu transportare, yang artinya trans adalah mengangkat atau membawa. Menurut Azis dan Asrul (2014) transportasi merupakan kebutuhan turunan dari kebutuhan ekonomi masyarakat. Jadi transportasi adalah suatu proses pemindahan objek baik manusia dan/atau barang guna memenuhi kebutuhan ekonomi.

\section{Bangkitan Perjalanan}

Menurut Miro (2005), bangkitan perjalanan diartikan sebagai banyaknya jumlah pergerakan lalulintas yang dibangkitan oleh suatu kawasan per satuan waktu. Bangkitan perjalanan (trip generation) terbentuk atas dua elemen penting yaitu:

- produksi perjalanan (trip production) yaitu perjalanan yang dibangkitan dari zona pemukiman.
- Tarikan perjalanan (trip attraction) yaitu tarikan yang ditimbulkan dari zona tujuan.

\section{Klasifikasi Perjalanan}

Tamin (2000) menjelaskan klasifikasi perjalanan sebagai berikut:

berdasarkan tujuan perjalanan yaitu:

a. Perjalanan ke tempat kerja

b. Pergerakan dengan tujuan pendidikan

c. Pergerakan ke tempat belanja.

d. Pergerakan untuk kepentingan sosial dan rekreasi.

berdasarkan jenis orang, (sosio-ekonomi):

a. Tingkat pendapatan

b. Tingkat pemilikan kendaraan

c. Ukuran dan struktur rumah.

\section{Faktor Bangkitan Perjalanan}

Menurut Tamin (2000), secara umum faktor-faktor yang berpengaruh terhadap bangkitan pergerakan perjalanan manusia yaitu pendapatan, kepemilikan kendaraan, struktur rumah tangga, ukuran rumah tangga, nilai lahan, kepadatan daerah permukiman dan aksesibilitas. Hamdi (2011) dalam kajiannya menyebutkan bahwa faktor-faktor yang mempengaruhi bangkitan perjalanan di Perumahan Bougenville Palembang adalah parameter ukuran keluarga, kepemilikan sepeda motor, dan jumlah penghasilan rata-rata keluarga.

Bella, et al (2013) melakukan pemodelan bangkitan perjalanan berbasis rumah tangga di Kompleks RSS Baumata Kupang. Faktor-faktor yang mempengaruhi bangkitan perjalanannya adalah tujuan perjalanan, anggota keluarga, kepemilikan kendaraan dan pendapatan rata-rata. Puspito (2016) melakukan kajian model bangkitan pergerakan di kawasan Perumahan Bengkuriang Samarinda. Faktor-faktor yang mempengaruhi bangkitan pergerakan di 
perumahan tipe bangunan mewah, menengah, dan sederhana yaitu jumlah anggota keluarga, jumlah kepemilikan mobil, jumlah kepemilikan motor dan jumlah anggota keluarga bersekolah. Bria, et al (2019) melakukan kajian model bangkitan perjalanan pada kawasan pinggiran menuju pusat kota yang mengalami perubahan spasial. Ditemukan bahwa faktor-faktor yang mempengaruhi bangkitan perjalanan adalah faktor rumah tangga seperti jumlah anggota keluarga, pendapatan dan kepemilikan kendaraan.

Misi Pemerintah Kota Bengkulu salah satunya adalah mewujudkan percepatan pembangunan infrastruktur perkotaan. Hal ini membuka peluang kepada dunia usaha untuk menyediakan dan mengembangkan sektor perumahan. Meningkatnya kegiatan pembangunan perumahan, pada akhirnya akan meningkatkan aktivitas bangkitan perjalanan masyarakat untuk memenuhi kebutuhan hidup sehari-hari.

Perumahan Medan Baru dan Perumahan Griya Azahra berada dalam kawasan Kecamatan Muara Bangkahulu, Kota Bengkulu. Lokasinya berdekatan dengan Kampus Universitas Bengkulu dan Pusat Pemerintahan Kota Bengkulu. Perumahan Medan Baru dan Perumahan Griya Azahra merupakan salah satu perumahan padat penduduk yang ada di Kecamatan Muara Bangkahulu sehingga aktivitas pergerakan orang untuk bekerja cukup signifikan.

Gambaran hasil penelitian yang ingin dicapai adalah teridentifikasinya faktorfaktor yang berpengaruh terhadap model bangkitan perjalanan bekerja pada Kawasan Perumahan di Kecamatan Muara Bangkahulu yang pada akhirnya dapat dijadikan referensi oleh pengembang perumahan dalam melakukan pembangunan perumahan dan perencanaan transportasi di kawasan perumahan untuk masa yang akan datang.

\section{METODE PENELITIAN}

Data penelitian diambil dari para responden yaitu masyarakat yang tinggal di Perumahan Medan Baru dan Perumahan Griya Azahra. Responden dipilih 1 orang dalam satu hunian berdasarkan anggota keluarga yang bekerja. Jumlah sampel dihitung dengan persamaan Slovin (Sugiyono, 2013)dengan tingkat toleransi kesalahan sebesar $10 \%$. Jumlah total populasi pada Perumahan Medan Baru dan Perumahan Griya Azahra adalah 1.055 jiwa. Perhitungan jumlah responden adalah:

$n=\frac{1.055}{1.055\left(10^{2}\right)+1}=92$ responden

Keterangan:

$N=$ Besarnya populasi

$d$ = Penyimpangan terhadap populasi atau derajat yang diinginkan

$n=$ jumlah responden.

\section{Variabel Penelitian}

Variabel penelitian terbagi atas variabel terikat dan variabel bebas. Variabel terikat dirumuskan sebagai jumlah bangkitan perjalanan bekerja (y) sedangkan variabel bebas adalah faktor sosioal-ekomomi dengan parameter:

1. Jumlah anggota keluarga $\left(\mathrm{x}_{1}\right)$

2. Jumlah kendaraan roda empat $\left(\mathrm{x}_{2}\right)$

3. Jumlah kendaraan roda dua $\left(\mathrm{x}_{3}\right)$

4. Jumlah penghasilan rata-rata keluarga perbulan $\left(\mathrm{x}_{4}\right)$

5. Jumlah anggota keluarga bekerja $\left(\mathrm{x}_{5}\right)$

Bangkitan perjalanan bekerja terkait erat dengan aksesibilitas perjalanan. Sehingga parameter aksesibilitas perjalanan bekerja adalah: 
1. Jarak tempuh ke tempat bekerja $\left(\mathrm{x}_{6}\right)$

2. Waktu tempuh ke tempat bekerja $\left(\mathrm{x}_{7}\right)$

3. Biaya operasional kendaraan $\left(\mathrm{x}_{8}\right)$

4. Jenis pekerjaan $\left(\mathrm{x}_{9}\right)$

5. Jenis kendaraan $\left(\mathrm{x}_{10}\right)$

6. Waktu berangkat bekerja $\left(\mathrm{x}_{11}\right)$

7. Waktu pulang bekerja $\left(\mathrm{x}_{12}\right)$

\section{Tahapan Pemodelan}

Alat bantu perangkat lunak yang digunakan dalam analisis pemodelan adalah SPSS Versi 16.0

\section{Uji Koefisien Korelasi}

Menurut Sugiyono (2013) analisa koefisien korelasi diperlukan untuk mengukur derajat keeratan hubungan antara variabel bebas dan variabel terikat.

\section{Regresi Linier Berganda}

Model regresi linier berganda yang digunakan yaitu (Sugiyono, 2013):

$y=a+b_{1} x_{1}+b_{2} x_{2}+b_{3} x_{3}+\ldots b_{n} x_{n}$

Keterangan:

$\mathrm{y}=$ variabel terikat

$\mathrm{a}=$ konstanta

$\mathrm{x}=$ variabel bebas

$\mathrm{b}=$ koefisien regresi

\section{Koefisien Determinasi}

Sugiyono (2013) menjelaskan jika nilai $r^{2}$ mendekati satu berarti variabel-variabel bebas memberikan hampir semua informasi yang dibutuhkan untuk memprediksi variabel terikat.

\section{Uji Multikolinieritas}

Sugiyono (2013) menyatakan bahwa Uji multikolinieritas digunakan untuk mengetahui ada atau tidaknya korelasi yang kuat diantara variabel bebas dengan melihat nilai Variance inflation Factor (VIF). Jika nilai tolerance $>0,10$ dan nilai VIF $<10,00$ maka tidak terjadi multikolinieritas.

\section{Uji T}

Pengujian dilakukan dengan menggunakan taraf signifikansi 0,05 . Jika nilai signifikansi $<0,05$ maka, ada pengaruh yang signifikan antara variabel bebas (x) dengan variabel terikat (x) sehingga hipotesis diterima. Jika nilai $t_{\text {hitung }}>$ dari $t_{\text {tabel }}$ maka ada pengaruh variabel bebas terhadap variabel terikat sehingga hipotesis diterima. (Ghozali, 2016)

\section{Uji F}

Jika nilai uji $f_{\text {hitung }} \geq f_{\text {tabel }}$ berarti variabel bebas mempunyai pengaruh secara signifikan terhadap variabel terikat demikian juga sebaliknya (Ghozali,2016).

\section{Uji Validasi}

Jika $r_{\text {hitung }}<r_{\text {tabel }}$ maka instrumen pertanyaan tidak berkorelasi signifikan terhadap skor total (Sugiyono,2013).

\section{Uji Liniertitas}

Jika nilai linierity > 0,05 maka hubungan antara variabel bebas dengan variabel terikat adalah linear. (Ghozali, 2016).

\section{Uji Heteroskedastisitas}

Menurut Santoso (2000) heteroskedastisitas terjadi jika titik-titik membentuk pola tertentu yang teratur seperti bergelombang, melebar kemudian menyempit.

\section{HASIL DAN PEMBAHASAN}

\section{Uji Koefisien Korelasi}

Hasil analisis koefisien korelasi antara variabel terikatbangkitan perjalanan bekerja (y)dengan variabel bebas faktor sosialekonomi dengan paramater jumlah anggota keluarga $\left(\mathrm{x}_{1}\right)$, jumlah kendaraan roda empat $\left(\mathrm{x}_{2}\right)$, jumlah kendaraan roda dua $\left(\mathrm{x}_{3}\right)$, jumlah penghasilan rata-rata keluarga 
perbulan $\left(\mathrm{x}_{4}\right)$ dan jumlah anggota keluarga bekerja $\left(\mathrm{x}_{5}\right)$ memiliki korelasi yang kuat. Sedangkan Hasil analisis koefisien korelasi antara variabel terikatbangkitan perjalanan bekerja (y) dengan variabel bebas aksesibilitas perjalanan dengan parameter jarak tempuh ke tempat bekerja $\left(\mathrm{x}_{6}\right)$, waktu tempuh ke tempat bekerja $\left(\mathrm{x}_{7}\right)$, biaya operasional kendaraan $\left(\mathrm{x}_{8}\right)$, jenis pekerjaan $\left(\mathrm{x}_{9}\right)$, jenis kendaraan $\left(\mathrm{x}_{10}\right)$, waktu berangkat bekerja $\left(\mathrm{x}_{11}\right)$ dan waktu pulang bekerja $\left(\mathrm{x}_{12}\right)$ memiliki korelasi yang lemah. Hasil ini mengharuskan variabel bebas aksesibilitas perjalanan bekerja tidak dilanjutkan untuk analisis berikutnya. Tabel 1 adalah hasil uji koefisien korelasi antara bangkitan perjalanan bekerja dengan faktor sosialekonomi dan Tabel 2 adalah hasil uji koefisien korelasi antara bangkitan perjalanan bekerja dengan aksesibilitas perjalanan bekerja.

Tabel 1. Hasil Uji Koefisien KorelasiBangkitan Perjalanan Bekerja dengan Faktor Sosial-Ekonomi

\begin{tabular}{|c|c|c|c|c|c|}
\hline & $\mathrm{x}_{1}$ & $\mathrm{x}_{2}$ & $\mathrm{x}_{3}$ & $\mathrm{x}_{4}$ & $\mathrm{x}_{5}$ \\
\hline $\mathrm{y}$ & 0,42 & 0,32 & 0,31 & 0,59 & 0,93 \\
\hline
\end{tabular}

Tabel 2. Hasil Koefisien KorelasiBangkitan Perjalanan Bekerja Dengan Aksesibilitas Perjalanan Bekerja

\begin{tabular}{|c|c|c|c|c|c|c|c|c|c|c|c|c|}
\hline & $\mathrm{x}_{1}$ & $\mathrm{x}_{2}$ & $\mathrm{x}_{3}$ & $\mathrm{x}_{4}$ & $\mathrm{x}_{5}$ & $\mathrm{x}_{6}$ & $\mathrm{x}_{7}$ & $\mathrm{x}_{8}$ & $\mathrm{x}_{9}$ & $\mathrm{x}_{10}$ & $\mathrm{x}_{11}$ & $\mathrm{x}_{12}$ \\
\hline $\mathrm{y}$ & 0,42 & 0,32 & 0,31 & 0,59 & 0,93 & $-0,09$ & $-0,15$ & 0,27 & $-0,39$ & $-0,07$ & 0,05 & $-0,08$ \\
\hline
\end{tabular}

\section{Regresi Linier Berganda}

Hasil analisis regresi linier berganda dua variabel didapatkan persamaan $\mathrm{y}=-0,774+$ $0,223 \mathrm{x}_{4}+1,290 \mathrm{x}_{5}$ dengan nilai $\mathrm{r}^{2}=0,879$.

Hasil analisis regresi linier berganda tiga variabel didapatkan persamaan $\mathrm{y}=-0,961+$ $0,173 \mathrm{x}_{1}+0,193 \mathrm{x}_{4}+1,257 \mathrm{x}_{5}$ dengan nilai $\mathrm{r}^{2}=0,886$. Hasil analisis regresi linier berganda empat variabel didapatkan persamaan $\mathrm{y}=-0,937+0,183 \mathrm{x}_{1}-0,056 \mathrm{x}_{2}$ $+0,217 \mathrm{x}_{4}+1,254 \mathrm{x}_{5}$ dengan nilai $\mathrm{r}^{2}=$ 0,887 . Hasil analisis regresi linier berganda lima variabel didapatkan persamaan $\mathrm{y}=$ $1,008+0,170 \mathrm{x}_{1}-0,051 \mathrm{x}_{2}+0,042 \mathrm{x}_{3}+$ $0,218 \mathrm{x}_{4}+1,248 \mathrm{x}_{5}$ dengan nilai $\mathrm{r}^{2}=0,887$.

\section{Uji Multikolinieritas}

Hasil uji multikolinieritas model regresi berganda dua, tiga, empat dan lima variabel semuanya menunjukkan bahwa nilai tolerance lebih dari 0,10 dan nilai VIF kurang dari 10,00 dalam artian tidak terjadi multikolinieritas sehingga semua model regresi berganda dapat dilanjutkan untuk uji berikutnya.

\section{Uji T}

Hasil Uji $\mathrm{T}$ untuk model regresi linier berganda dua variabel didapatkan nilai $\mathrm{t}_{\text {hitung }} \mathrm{X}_{4}=3,501$ dan $\mathrm{t}_{\text {hitung }} \mathrm{X}_{5}=19,848$. Hasil Uji $\mathrm{T}$ untuk model regresi linier berganda tiga variabel didapatkan nilai $\mathrm{t}_{\text {hitung }} \mathrm{X}_{1}=$ 2,$347 ; \mathrm{t}_{\text {hitung }} \mathrm{x}_{4}=3,041 \quad$ dan $\quad \mathrm{t}_{\text {hitung }} \mathrm{x}_{3}=$ 19,358. Hasil Uji $\mathrm{T}$ untuk model regresi linier berganda empat variabel didapatkan nilai $\mathrm{t}_{\text {hitung }} \mathrm{X}_{1}=2,427 ; \quad \mathrm{t}_{\text {hitung }} \mathrm{X}_{2}=\quad-$ 0,$668 ; \mathrm{t}_{\text {hitung }} \mathrm{X}_{4}=2,979 \quad$ dan $\quad \mathrm{t}_{\text {hitung }} \mathrm{X}_{5}=$ 19,227. Hasil Uji T untuk model regresi linier berganda lima variabel didapatkan nilai $\mathrm{t}_{\text {hitung }} \mathrm{X}_{1}=2,101 ; \quad \mathrm{t}_{\text {hitung }} \mathrm{X}_{2}=-0,598$; $t_{\text {hitung }} \mathrm{X}_{3}=0,440 ; \mathrm{t}_{\text {hitung }} \mathrm{X} 4=2,982$ dan $\mathrm{t}_{\text {hitung }} \mathrm{X}_{5}=18,591$.

Berdasarkan distribusi tabel nilai $\mathrm{t}$ pada standard error (e) $=5 \%$ atau 0,05 didapatkan nilai $\mathrm{t}_{\text {tabel }}$ sebesar 1,663. Untuk mengidentifikasi seberapa jauh pengaruh satu variabel bebas terhadap variabel terikat

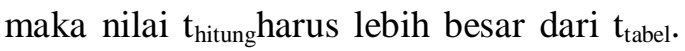
Dengan demikian model persamaan yang berpengaruh secara signifikan antara variabel bebas (x) terhadap variabel terikat (y) yaitu model persamaan regresi berganda dua variabel, $\mathrm{y}=-0,774+0,223 \mathrm{x}_{4}+1,290$ $\mathrm{x}_{5} \mathrm{dan}$ model persamaan regresi berganda 
tiga variabel, $\mathrm{y}=-0,961+0,173 \mathrm{x}_{1}+0,193$ $\mathrm{x}_{4}+1,257 \mathrm{x}_{5}$.

\section{Uji F}

Hasil uji $\mathrm{F}$ menunjukkan bahwa untuk model persamaan regresi berganda dua variabel nilai $\mathrm{f}_{\text {hitung }}=323,476$ lebih besar dari $\mathrm{f}_{\text {tabel }} 2,21$. Untuk model persamaan regresi berganda tiga variabel nilai $\mathrm{f}_{\text {hitung }}=$ 228,414 lebih besar dari $f_{\text {tabel }}=2,21$. Dengan demikian ada pengaruh secara signifikan antara jumlah anggota keluarga $\left(\mathrm{x}_{1}\right)$, jumlah penghasilan rata-rata keluarga perbulan $\left(\mathrm{x}_{4}\right)$ dan jumlah anggota keluarga bekerja $\left(\mathrm{x}_{5}\right)$ terhadap jumlah bangkitan perjalanan bekerja $(\mathrm{y})$.

\section{Uji Validasi}

Dilihat dari nilai correct item-total correlation, untuk model regresi berganda dua variabeljumlah penghasilan rata-rata keluarga perbulan $\left(\mathrm{x}_{4}\right)$ nilai $\mathrm{r}_{\text {hitung }}=0,567$ lebih besar dari $r_{\text {tabel }}=0,204$ dan jumlah anggota keluarga bekerja $\left(\mathrm{x}_{5}\right)$ nilai $\mathrm{r}_{\text {hitung }}=$ $0,850>r_{\text {tabel }}=0,204$. Terdapat korelasi yang signifikan antara jumlah penghasilan rata-rata keluarga perbulan $\left(\mathrm{x}_{4}\right)$ dan jumlah anggota keluarga bekerja $\left(\mathrm{x}_{5}\right)$ terhadap jumlah bangkitan perjalanan bekerja (y).

Untuk model regresi berganda tiga variabel, nilai correct item-total correlation jumlah anggota keluarga $\left(\mathrm{x}_{1}\right)$ nilai $\mathrm{r}_{\text {hitung }}=0,424$ lebih besar dari $r_{\text {tabel }}=0,204$. Untuk Jumlah penghasilan rata-rata keluarga perbulan $\left(\mathrm{x}_{4}\right)$ $\mathrm{r}_{\text {hitung }}=0,579>\mathrm{r}_{\text {tabel }}=0,204$ dan jumlah anggota keluarga bekerja $\left(\mathrm{x}_{5}\right)$ nilai $\mathrm{r}_{\text {hitung }}=$ $0,813>r_{\text {tabel }}=0,204$. Dengan demikian dapat dinyatakan bahwa terdapat korelasi yang signifikan antara jumlah anggota keluarga $\left(\mathrm{x}_{1}\right)$, jumlah penghasilan rata-rata keluarga perbulan $\left(\mathrm{x}_{4}\right)$ dan jumlah anggota keluarga bekerja $\left(\mathrm{x}_{5}\right)$ dengan jumlah bangkitan perjalanan bekerja (y).

\section{Uji Linieritas}

Dari uji linieritas untuk model regresi berganda dua variabel dan tiga variabel, didapatkannilai signifikansi sebesar 1,000 lebih besar dari 0,05. Dengan demikian persamaan $\mathrm{y}=-0,774+0,223 \mathrm{x}_{4}+1,290 \mathrm{x}_{5}$ dan $\mathrm{y}=-0,961+0,173 \mathrm{x}_{1}+0,193 \mathrm{x}_{4}+$ $1,257 \mathrm{x}_{5}$ dinyatakan bahwa hasil pemodelan sudah tepat dan memiliki hubungan linier.

\section{Uji Heteroskedastisitas}

Hasil uji heteroskedastisitas dapat dilihat pada Gambar 1. dan Gambar 2.

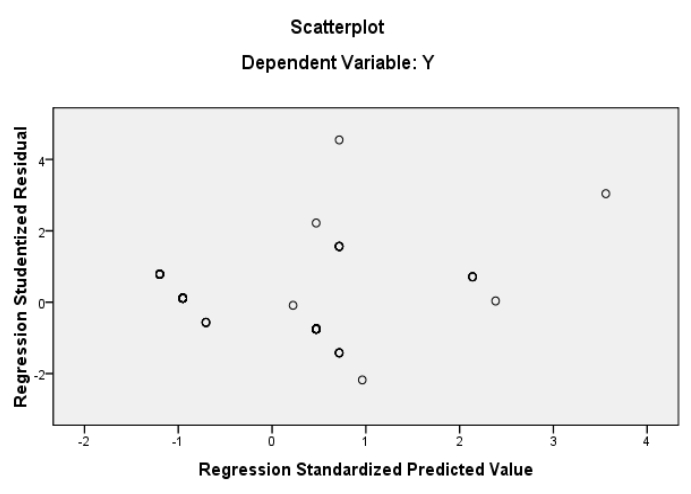

Gambar 1. Hasil Uji Heteroskedastisitas Model Regresi Berganda Dua Variabel

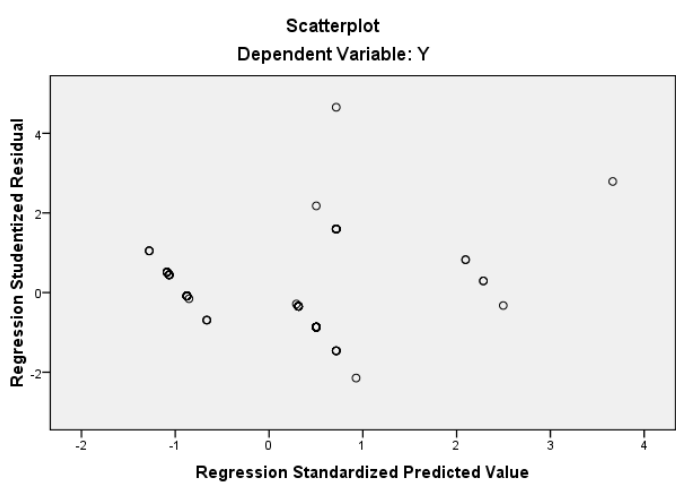

Gambar 2. Hasil Uji Heteroskedastisitas Model Regresi Berganda Tiga Variabel

Berdasarkan Gambar 1. dan Gambar 2. dapat dilihat bahwa titik-titik observasi menyebar di atas dan di bawah angka 0 pada sumbu Y. Dengan demikian tidak terjadi gejala heteroskedastisitas pada model regresi berganda dua variabel dan tiga variabel. 
Hasil akhir dari proses analisis statistik dapatkan bahwa model regresi linier berganda tiga variabel yang memiliki persamaan $\mathrm{y}=-0,961+0,173 \mathrm{x}_{1}+0,193 \mathrm{x}_{4}$ $+1,257 \mathrm{x}_{5}$, dengan $\mathrm{r}^{2}=0,886$ adalah persamaan terbaik untuk mendapatkan hubungan antara bangkitan perjalanan bekerja (y)dengan faktor sosial-ekonomi (x) berupa jumlah anggota keluarga $\left(\mathrm{x}_{1}\right)$, jumlah penghasilan rata-rata keluarga perbulan $\left(\mathrm{x}_{4}\right)$ dan jumlah anggota keluarga bekerja $\left(\mathrm{x}_{5}\right)$.

\section{KESIMPULAN}

Faktor-faktor yang berpengaruh terhadap model bangkitan perjalanan bekerja (y)pada kawasan perumahan di Kecamatan Muara Bangkahulu Kota Bengkulu adalahjumlah anggota keluarga $\left(\mathrm{x}_{1}\right)$, jumlah penghasilan rata-rata keluarga perbulan $\left(\mathrm{x}_{4}\right)$ dan jumlah anggota keluarga bekerja $\left(\mathrm{x}_{5}\right)$.Model bangkitan perjalanan bekerja memiliki persamaan $\mathrm{y}=-0,961+0,173 \mathrm{x}_{1}+0,193 \mathrm{x}_{4}$ $+1,257 x_{5}$, dengan $r^{2}=0,886$. Hal ini menunjukkan bahwa bangkitan perjalanan bekerja akan meningkatseiring dengan bertambahnya jumlah anggota keluarga, jumlah penghasilan rata-rata keluarga perbulan dan jumlah anggota keluarga bekerja. Akibat aktivitas bangkitan perjalanan yang terus meningkat, tingkat pelayanan jalan menjadi menurun. Untuk itu instansi yang berwenang perlu mengantisipasi dengan cara melakuan evaluasi kinerja jalan secara periodik.

\section{DAFTAR PUSTAKA}

Azis, R., Asrul. 2014. Pengantar Sistem Perencanaan Transportasi.
Bella, R.A.K. Malaikosa, dan L. W. Fanggidae. 2013. Pemodelan Bangkitan Perjalanan Berbasis Rumah Tangga di Kompleks RSS Baumata Kecamatan Taebenu Kabupaten Kupang. Jurnal Teknik Sipil II(1): 6370.

Bria, T. A. T. Wonlele, dan O. Loden. 2019. Model Bangkitan Perjalanan Pada Kawasan Pinggiran Menuju Pusat Kota (Studi Pada Kawasan Yang mengalami Perubahan Spasial). Potensi21(2): 54-60.

Ghozali, H. I.2016. Aplikasi Analisis Multivariete Dengan Program IBM SPSS 23.Edisi Delapan. Cetakan kedelapan.Badan PenerbitUniversitas Diponegoro.Semarang.

Hamdi.2011. Bangkitan Perjalanan Pada Perumahan Bougenville di Palembang. Jurnal Sipil5(2): 1-6.

Miro, F., 2005. Pengantar Sistem Transportasi. Penerbit Erlangga. Jakarta.

Puspito, N. D.2016. Model Bangkitan Pergerakan di Kawasan Perumahan Bengkuriang Samarinda. Ejurnal Kurva S 1(1): 1-14.

Sugiyono. 2013. Metode Penelitian Pendidikan Pendekatan Kuantitatif, Kualitatif, dan R\&D. Penerbit Alfabeta. Bandung.

Tamin, O. Z. 2000. Perencanaan dan Pemodelan Transportasi. Edisi Kedua. Penerbit ITB. Bandung. 